\title{
Role of melt supply in oceanic detachment faulting and formation
}

\section{of megamullions}

\author{
Brian E. Tucholke ] Department of Geology and Geophysics, Woods Hole Oceanographic Institution, Woods Hole, \\ Mark D. Behn J Massachusetts 02543, USA \\ W. Roger Buck Lamont-Doherty Earth Observatory of Columbia University, Palisades, New York 10964, USA \\ Jian Lin Department of Geology and Geophysics, Woods Hole Oceanographic Institution, Woods Hole, Massachusetts 02543, USA
}

\section{ABSTRACT}

Normal faults are ubiquitous on mid-ocean ridges and are expected to develop increasing offset with reduced spreading rate as the proportion of tectonic extension increases. Numerous long-lived detachment faults that form megamullions with large-scale corrugations have been identified on magma-poor mid-ocean ridges, but recent studies suggest, counterintuitively, that they may be associated with elevated magmatism. We present numerical models and geological data to show that these detachments occur when $\sim 30 \%-50 \%$ of total extension is accommodated by magmatic accretion and that there is significant magmatic accretion in the fault footwalls. Under these low-melt conditions, magmatism may focus unevenly along the spreading axis to create an irregular brittle-plastic transition where detachments root, thus explaining the origin of the enigmatic corrugations. Morphological and compositional characteristics of the oceanic lithosphere suggested by this study provide important new constraints to assess the distribution of magmatic versus tectonic extension along mid-ocean ridges.

Keywords: mid-ocean ridge, detachment fault, megamullion, oceanic core complex, oceanic magmatism, numerical modeling.

\section{INTRODUCTION}

There is ongoing debate about the role of magmatism during normal faulting at mid-ocean ridges (MORs), particularly for very long-lived ( 1-2 m.y.) normal faults, which we here term detachment faults. Plate separation at MORs is accomplished by both magmatic intrusion and slip on normal faults. Intrusion of dikes can occur when the difference between maximum and minimum stresses is lower than that required for fault slip, and intrusion further reduces the stress difference (Rubin, 1995). This implies that major normal faults should form only when there is little or no magma supply. Some numerical models also suggest that detachments can form during amagmatic extension if the lithosphere is thin and cohesion decreases with fault displacement (Lavier et al., 2000). These ideas are consistent with the observation that most detachment faults occur at the ends of spreading segments where melt supply is usually low compared to segment centers (e.g., Lin et al., 1990; Tucholke et al., 1998). Furthermore, large tracts of unusually smooth seafloor, interpreted as successive fault surfaces, have been observed on the ultraslow-spreading Southwest Indian Ridge, where magmatism is extremely limited (Cannat et al., 2006).

In contrast, some recent observations suggest that magmatism may be important during the evolution of detachment faults. Because of their long-lived slip, these faults can exhume tens of kilometers of lower ocean crust and upper mantle. To maintain isostatic equilibrium, the footwalls typically roll over (Buck, 1988) and form megamullions characterized by domed shapes and by large (to hundreds of meters), enigmatic, fault-surface corrugations as well as smaller mullions and striations that parallel fault-slip direction (Tucholke et al., 1998) (Fig. 1A). Three megamullions have been drilled, two on the Mid-Atlantic Ridge and one on the Southwest Indian Ridge, and in each case thick (up to $1.4 \mathrm{~km}$ ) gabbros were cored, indicating a strong magmatic component (Dick et al., 2000; Kelemen et al., 2004; Blackman et al., 2006). Furthermore, if detachment

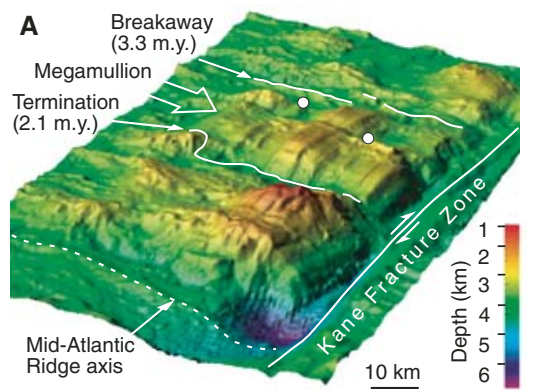

Figure 1. Characteristics of megamullions formed by detachment faults. A: Three-dimensional view of Kane megamullion (center) on the Mid-Atlantic Ridge (MAR), looking southwest; note large, slip-parallel corrugations on detachment surface and high-angle, outwardfacing normal faults (dots) that interrupt detachment.
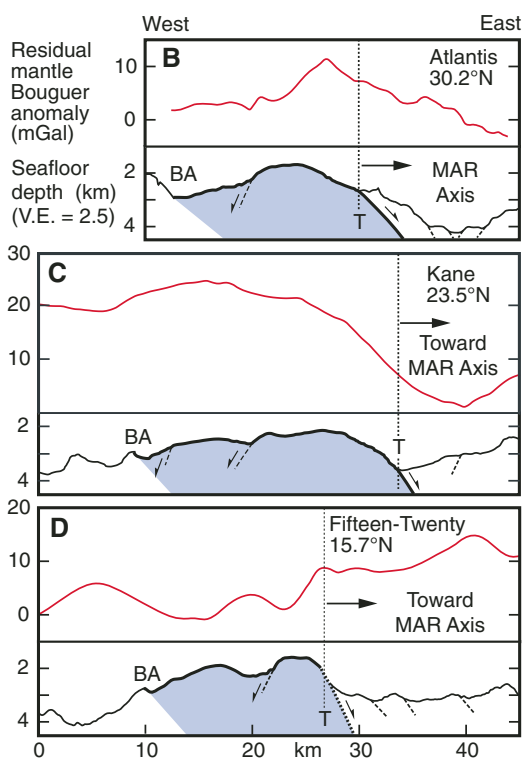

B-D: Residual mantle Bouguer gravity anomaly (RMBA), seafloor topography, and structural interpretation for three megamullions (shaded) formed by detachment faults (bold lines) on the MAR. Breakaways (BA) and terminations $(T)$ are indicated. Bold lines are intact fossil detachments in $A$ and $B$; bold dotted line in $C$ is high-angle fault that incised detachment to form new plate boundary. Other high-angle normal faults cutting detachments or surrounding seafloor are dashed. Profile data extracted from Blackman et al. (1998), Tucholke et al. (1998), and Fujiwara et al. (2003).

faulting were enhanced with increased tectonic extension, megamullions should be abundant on slower-spreading ridges, but their frequency there is limited. For example, they cover only $4 \%$ of the seafloor on the ultraslow Southwest Indian Ridge (Cannat et al., 2006), and none have been identified on Gakkel Ridge, the slowest-spreading MOR on Earth (Dick et al., 2003; Michael et al., 2003).

To explore these conflicting observations, we used numerical models and analyzed geological data for megamullions to assess the role of magmatism in normal faulting. We conclude that continuous detachment faults develop at intermediate levels of magma supply $(\sim 30 \%-50 \%$ of total plate separation). We also suggest that large-scale corrugations on detachments are linked to irregular along-axis shape of the brittle-plastic transition above magmatic intrusions, which implies that magmatism is an integral part of megamullion formation.

\section{NUMERICAL MODELING}

We conducted two-dimensional numerical modeling of extension of an elastic-viscoplastic layer with temperature-dependent viscosity structure and depth-dependent plastic shear yield (see the 
GSA Data Repository ${ }^{1}$ for details and videos of model runs). In these models, a fraction, $M$, of total plate separation is taken up by continuous melt accretion in a vertical, 6-km-high magma-intrusion zone fixed at a spreading axis. Buck et al. (2005) and Behn et al. (2006) reported this kind of modeling for values of $M \geq 0.5$. Unlike those models, we examined cases for $M<0.5$ (as well as higher $M$ cases), and we also accounted for advective and conductive heat transport plus addition of heat due to magma emplacement. Models were run at a full spreading rate of $50 \mathrm{~mm} / \mathrm{yr}$, roughly at the transition from slow to intermediate rates at MORs.

For model runs with $M \geq 0.5$, our results are comparable to those of Buck et al. (2005). At $M>0.5$, more than half of plate separation is accommodated by magmatism, and faults must migrate off axis. The integrated strength of a fault increases as lithosphere cools and thickens with distance from the axis, so a fault eventually becomes inactive and is replaced by a new, near-axis fault (Fig. 2A). Faults break alternately on opposite sides of the rift axis, producing normal abyssal hills that are grossly symmetrical on the two ridge flanks.

At $M=0.5$ a master detachment fault forms because the fault ceases to migrate. It accommodates half the plate separation in the brittle layer and continuously roots at the brittle-plastic transition $\left(\sim 600^{\circ} \mathrm{C}\right)$ slightly above the base of the intrusion zone (Fig. 2B). Between the base of the detachment and the bottom of the intrusion zone, model flow vectors indicate that magma accretes in the footwall at rates up to $\sim 20 \mathrm{~mm} / \mathrm{yr}$ (Fig. 2B, inset). In the conjugate plate, extension is taken up largely by melt accretion at shallow levels and there is only minor normal faulting.

As $M$ is reduced below 0.5 , the master detachment migrates in the direction of the hanging wall because of the accretion deficit in the conjugate plate. At $M=0.4$ (Fig. 2C), high-angle antithetic faults in the hanging wall take up part of the accretion deficit and create abyssal hills. As accretion is progressively reduced $(M=0.3, M=0.2$; Figs. $2 \mathrm{D}$ and $2 \mathrm{E})$, the trace of the master fault migrates faster and high-angle faults break the hanging wall, the footwall, or both, with increasing frequency. Most of the highangle faults are antithetic, although a few are synthetic, and most initiate very close to the plate boundary and are active to only a few kilometers off axis. Some antithetic faults are captured in the footwall of the master fault to form outward-facing scarps, while others temporarily become the master fault and thus cause a reversal of slip direction at the spreading axis. Magma accretes at variable rates in the footwall of all faults that intersect the intrusion zone. Because of footwall rollover, high-angle faults that cut the footwall of a master fault commonly are reoriented to near vertical, or even overturned, thus acquiring the orientation of a thrust fault at the seafloor (dashed fault, Fig. 2D).

When there is no melt accretion $(M=0)$, all extension is taken up by normal faults (Fig. 2F), but long-lived detachments do not form. Most faults are active for $<0.2 \mathrm{~m}$.y. and alternate irregularly in position and dip direction between the two ridge flanks. Normally the plate boundary is defined by one master fault, although two faults may be active at one time. It might be expected that a single detachment fault could persist, continuously exhuming mantle and migrating in the direction of the hanging wall. However, the models indicate that advected heat weakens the footwall and allows bending stresses to generate a new fault, either inward or outward facing, that later becomes the master fault. Thus a master fault migrates only a few kilometers before it is replaced by a new fault.

Our modeling results are consistent with conceptual models that the duration of fault slip is greatest for a moderate supply of melt (Buck et al., 2005). Long-lived detachments appear to form only within a limited win-

${ }^{1}$ GSA Data Repository item 2008111, numerical modeling methods, videos DR1-DR6 of numerical models, and determination of megamullion frequency, is available online at www.geosociety.org/pubs/ft2008.htm, or on request from editing@geosociety.org or Documents Secretary, GSA, P.O. Box 9140, Boulder, CO 80301, USA.
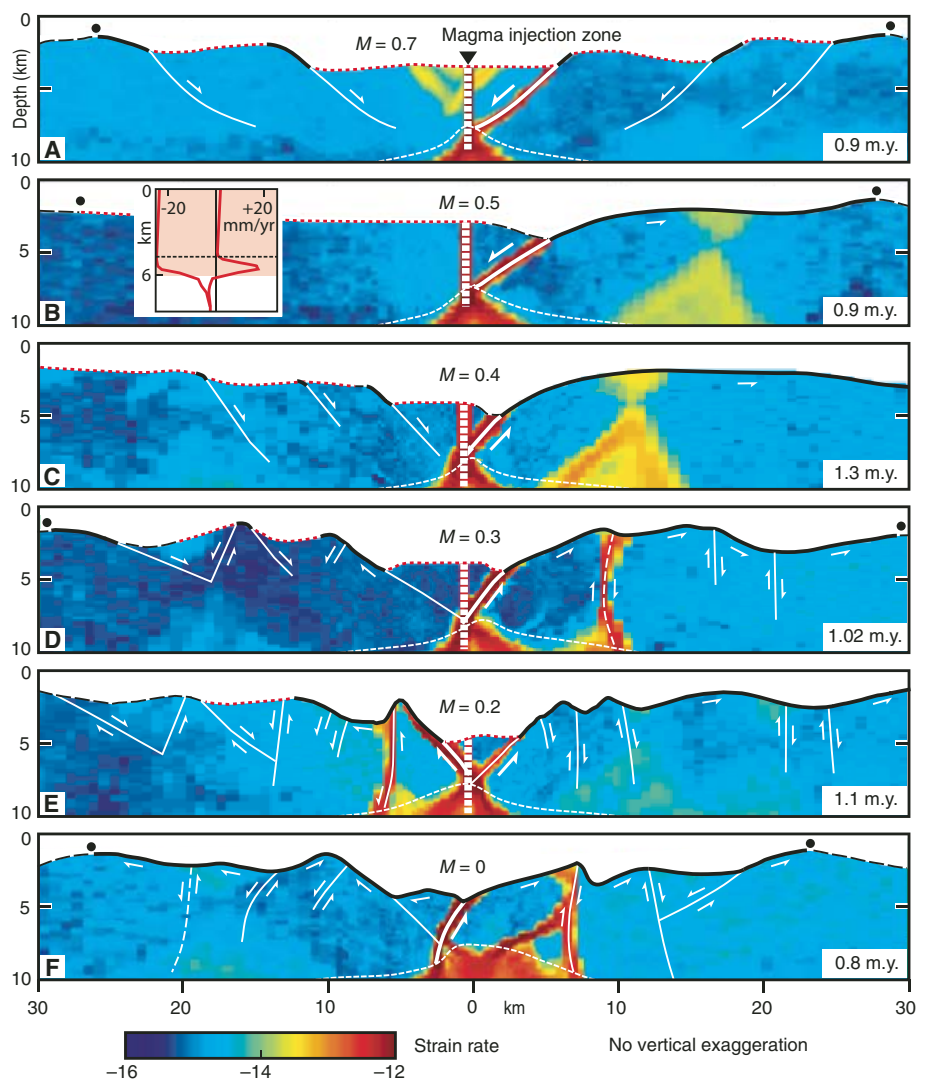

Figure 2. A-F: Snapshots of modeled fault behavior for values of $M$ (the fraction of total plate separation taken up by accretion of melt) between 0.7 and 0 (see footnote 1 for details and videos of model runs). Geologic interpretation is superimposed on modeled distribution of strain rate. In each panel model time is indicated at lower right, and dashed line at bottom is $600{ }^{\circ} \mathrm{C}$ isotherm (approximate brittle-plastic transition). Dots show breakaways of initial faults. Dashed seafloor is original model seafloor, red dotted seafloor is formed dominantly by magmatic accretion, and solid bold is fault surface. Note that detachments in B and C are not interrupted by secondary faults. Dashed, near-vertical faults initiated $\geq 4 \mathrm{~km}$ off axis. Model topography becomes subdued away from spreading axis due to regridding. Inset in B shows direction and magnitude $(\mathrm{mm} / \mathrm{yr})$ of flow of material in each plate immediately adjacent to 6-km-high magma injection zone (shaded); dashed horizontal line is depth where detachment intersects injection zone.

dow where there is neither too much nor too little magmatism, but just the right amount to facilitate fault slip. We assess geological evidence for this "Goldilocks hypothesis" in the next section.

\section{GEOLOGICAL OBSERVATIONS}

We examined field data to investigate the relationship between magma supply and duration of slip for the long-lived detachment faults that form megamullions. We first considered gravity signatures over these features. Most megamullions have elevated residual mantle Bouguer gravity anomaly (RMBA) compared to crust on the young side of the detachment termination (Figs. 1B and 1C), and they also are associated with elevated RMBA along seafloor isochrons beyond the limits of the detachment fault in the enclosing spreading segment. The elevated RMBA suggests that the crust is thin and thus that megamullions form during periods of reduced magmatism. Lower RMBA beyond the termination implies thicker crust and indicates that the detachment fault was abandoned when magmatism increased, presumably because a new fault 
formed in weakened axial-valley crust (Tucholke et al., 1998). In contrast, some megamullions show an RMBA increase across the termination (Fig. 1D), which implies that the detachment was abandoned when magmatism was reduced. The gravity data thus suggest that detachments operate at intermediate levels of magmatism.

We further investigated the tectonomagmatic relations by determining the frequency of occurrence of megamullions within $98 \mathrm{MOR}$ segments that represent the full range of global spreading rates (see the Data Repository). In Figure 3, we plot megamullion frequency per unit area in each spreading segment against average axial depth, which was used as a proxy for magma supply. Axial morphology and depth have been shown to be sensitive to mantle temperature, crustal thickness, and thus magma supply (e.g., Hooft and Detrick, 1995). Figure 3A shows that the most magmatic MORs, represented by shallow axial depths, do not develop megamullions. These features first appear when axial depths reach 3500-3700 $\mathrm{m}$, followed by a general increase in frequency with increasing axial depth to $\sim 4500-4600 \mathrm{~m}$. A sharp drop in megamullion frequency occurs at $\sim 4700-4800 \mathrm{~m}$, and there are only a few possible examples at greater depths.

Faster-spreading MORs are generally more magmatic than those that spread slowly, so we also plotted megamullion frequency against full spreading rate (Fig. 3B). Megamullions do not form at rates $>\sim 76 \mathrm{~mm} / \mathrm{yr}$, but a large number occur at intermediate-rate MORs (50-76 mm/yr) that have restricted magma supply, primarily at the Australia-Antarctic Discordance (Okino et al., 2004), the Parece-Vela backarc basin (Ohara et al., 2001), and the Central and Southeast Indian ridges. Megamullions are most common at spreading rates of $\sim 14-32 \mathrm{~mm} / \mathrm{yr}$ on the Mid-Atlantic Ridge and Southwest Indian Ridge; none are known to develop at rates $<\sim 14 \mathrm{~mm} / \mathrm{yr}$.

These data show that detachment faults form megamullions when magma is present at moderately low levels. However, detachments appear not to form, or do not persist for long, when magmatism is extremely limited.

\section{DISCUSSION AND CONCLUSIONS}

The modeling results and geological observations (Figs. 2 and 3) are mutually consistent and indicate that conditions of high or very low magma supply do not favor detachment faulting. For most megamullions, ocean crust observed on the conjugate ridge flank exhibits faulted abyssal hills and volcanic morphology (e.g., Canales et al., 2004); this demonstrates that, at a minimum, some magma is supplied to the hanging wall. Model topography and distribution of seafloor volcanic rocks developed in the conjugate flank at $M=0.4$ (Fig. 2C) are most similar to seafloor observations, although abyssal hills can develop at $M=0.5$ with slightly different model parameters (Buck et al., 2005). As $M$ is reduced below 0.4 , the extent of seafloor formed by faulting progressively increases, but the integrity of a master detachment is degraded and eventually is consistently interrupted by high-angle normal faults (Figs. 2D-2F). The combined geological and modeling results therefore suggest that detachment faults are most likely to form megamullions when $\sim 0.3 \leq M \leq 0.5$. The models also indicate significant intrusion of magma into detachment footwalls (Fig. 2B, inset), which explains the presence of thick $(>1.4 \mathrm{~km})$ gabbro sections that have been drilled at megamullions on the Mid-Atlantic Ridge and Southwest Indian Ridge.

Slip on a detachment fault probably terminates in one of two ways. When $M$ increases to $>0.5$, the fault will be forced off axis and replaced by a near-axis fault, as in Figure 2A. This preserves the trace of the detachment and results in decreasing RMBA (thicker crust) in younger crust (Figs. $1 \mathrm{~B}$ and $1 \mathrm{C}$ ). If magmatism decreases to $<\sim 0.3$, the detachment footwall will be broken by a new master fault (Figs. 2E and $2 \mathrm{~F}$ ), with the likely result that the crust is thinned further and RMBA increases (Fig. 1D). Such footwall rifting has been described for the Mid-Atlantic Ridge near
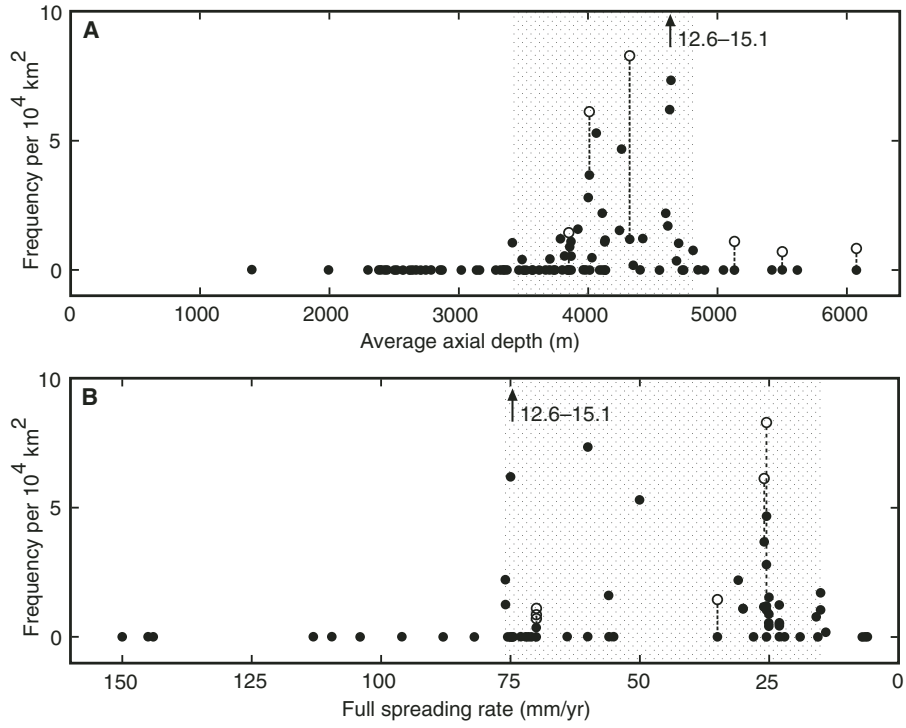

Figure 3. Plots of megamullion frequency versus average ridge-axis depth (A) and full spreading rate (B). Each data point represents one mid-ocean ridge (MOR) spreading segment. Open circles and dashed lines show where additional megamullions may be present, but their identification is not well constrained by available multibeam bathymetric data. Arrows indicate values outside limits of plots.

lat $5^{\circ} \mathrm{S}$, where remnants of a split megamullion appear on conjugate ridge flanks and seismic refraction data from the intervening rift valley show unusually thin crust $(\sim 3 \mathrm{~km})$ (Reston et al., 2002).

At very low values of $M(\leq 0.2)$, the seafloor may consist almost entirely of fault surfaces (Figs. 2E and 2F). This morphology is similar to the large tracts of unusually smooth seafloor offset by high-angle normal faults at $\sim 10 \mathrm{~km}$ spacing on the Southwest Indian Ridge (Cannat et al., 2006). Cannat et al. (2006) noted that these areas have elevated RMBA and common exposures of mantle rocks, consistent with very low melt supply.

Episodic, spatially variable magmatism in very low- $M$ environments may explain why megamullions have large-scale corrugations (e.g., Fig. 1A). Intrusion of magma along the spreading center is probably irregular and would produce an uneven brittle-plastic transition; thus any detachment rooting in this transition could develop corrugations on the exhumed footwall, even if the initial fault trace at the breakaway were relatively linear (Fig. 4). Once established, the cool hanging-wall mold could continue to control the shape of the exhuming footwall (with or without further magmatic injections) by means of "continuous casting" (Spencer, 1999). On the Southwest Indian Ridge, corrugated megamullions with reduced RMBA interrupt the smooth seafloor (Cannat et al., 2006), which implies that detachments forming the megamullions operated under conditions of locally increased magmatism. If the proposed link between magmatism and large-scale fault corrugation is correct, then corrugation morphology should predict the distribution of ambient melt at the time a detachment fault first formed. Similar linkage of detachment faults to deep gabbro intrusions was been proposed by Ildefonse et al. (2007).

There is open debate about whether detachments at MORs are high angle $\left(\sim 45^{\circ}-60^{\circ}\right)$ in the subsurface, as predicted from Andersonian fault theory (Thatcher and Hill, 1995), or low angle $\left(25^{\circ}-35^{\circ}\right)$, as is observed at detachment terminations (Tucholke et al., 1998) (Figs. 1B-1D). Our numerical models suggest that the faults dip steeply at depth but that footwall rollover reduces dip angle at shallow levels (Fig. 2). The resulting bending stresses explain footwall failure near the spreading axis, and they also have implications for melt transport (Tucholke et al., 2001). If melt is present in the bending footwall, compression below the neutral 


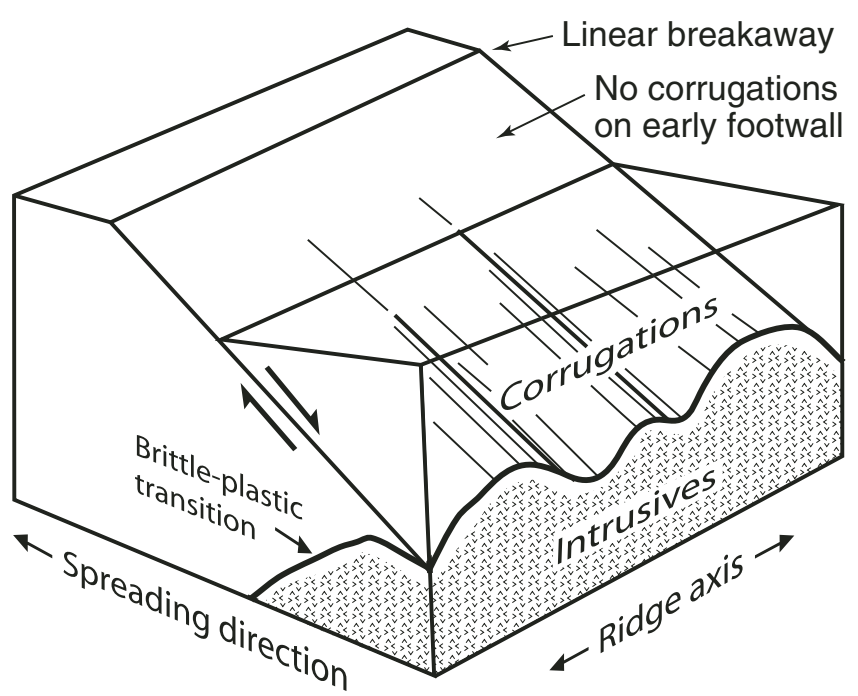

Figure 4. Schematic diagram showing how large-scale corrugations may develop on megamullion surface. Detachment breakaway is linear but fault is corrugated at depth, following an irregular brittleplastic transition above intrusions; footwall exhumation eventually exposes these corrugations.

plane should force it into the extending upper reaches of the footwall. Thus we predict that zones of weakness in the footwall such as secondary high-angle faults may be commonly associated with magmatic intrusions and surficial volcanism.

Our analyses suggest predictable, semiquantitative patterns of fault characteristics in relation to melt supply. These observations provide important new constraints to evaluate the distribution and evolution of magmatic versus tectonic extension along mid-ocean ridges.

\section{ACKNOWLEDGMENTS}

This research was supported by the National Science Foundation and by the Henry Bryant Bigelow Chair in Oceanography to Tucholke at Woods Hole Oceanographic Institution. We thank Y. Ohara, R. Searle, J. Karsten, and F. Martinez for providing multibeam bathymetric data, H.J.B. Dick, J.R. Cann, and G. Ito for helpful discussions, and R. Searle, T. Schroeder, and T. Fujiwara for thoughtful reviews.

\section{REFERENCES CITED}

Behn, M.D., Buck, W.R., and Sacks, I.S., 2006, Topographic controls on dike injection in volcanic rift zones: Earth and Planetary Science Letters, v. 246, p. 188-196, doi: 10.1016/j.epsl.2006.04.005.

Blackman, D.K., Cann, J.R., Janssen, B., and Smith, D.K., 1998, Origin of extensional core complexes: Evidence from the Mid-Atlantic Ridge at Atlantis Fracture Zone: Journal of Geophysical Research, v. 103, p. 21,315-21,333, doi: 10.1029/98JB01756.

Blackman, D.K., Ildefonse, B., John, B.E., Ohara, Y., Miller, D.J., MacLeod, C.J., and Expedition 304/305 Scientists, 2006, Proceedings of the Integrated Ocean Drilling Program, Volume 304/305: College Station, Texas, Integrated Ocean Drilling Program, doi: 10.2204/iodp.proc.304305.2006.

Buck, W.R., 1988, Flexural rotation of normal faults: Tectonics, v. 7, p. 959-973.

Buck, W.R., Lavier, L.L., and Poliakov, A.N.B., 2005, Modes of faulting at midocean ridges: Nature, v. 434, p. 719-723, doi: 10.1038/nature03358.

Canales, J.P., Tucholke, B.E., and Collins, J.A., 2004, Seismic reflection imaging of an oceanic detachment fault: Atlantis megamullion (Mid-Atlantic Ridge, $30^{\circ} 10^{\prime} \mathrm{N}$ ): Earth and Planetary Science Letters, v. 222, p. 543-560, doi: 10.1016/j.eps1.2004.02.023.

Cannat, M., Sauter, D., Mendel, V., Ruellan, E., Okino, K., Escartin, J., Combier, V., and Baala, M., 2006, Modes of seafloor generation at a melt-poor ultraslow-spreading ridge: Geology, v. 34, p. 605-608, doi: 10.1130/ G22486.1.

Dick, H.J.B., and Shipboard Party of Leg 176, 2000, A long in situ section of the lower ocean crust: Results of ODP Leg 176 drilling at the Southwest Indian Ridge: Earth and Planetary Science Letters, v. 179, p. 31-51, doi: 10.1016/ S0012-821X(00)00102-3.

Dick, H.J.B., Lin, J., and Schouten, H., 2003, An ultraslow-spreading class of ocean ridge: Nature, v. 426, p. 405-412, doi: 10.1038/nature02128.

Fujiwara, T., Lin, J., Matsumoto, T., Kelemen, P.B., Tucholke, B.E., and Casey, J.F., 2003, Crustal evolution of the Mid-Atlantic Ridge near the FifteenTwenty Fracture Zone in the last 5 Ma: Geochemistry, Geophysics, Geosystems, v. 4, doi: 10.1029/2002GC000364.

Hooft, E.E.E., and Detrick, R.S., 1995, Relationship between axial morphology, crustal thickness, and mantle temperature along the Juan de Fuca and Gorda Ridges: Journal of Geophysical Research, v. 100, p. 22,499-22,508, doi: 10.1029/95JB02502.

Ildefonse, B., Blackman, D.K., John, B.E., Ohara, Y., Miller, D.J., MacLeod, C.J., and Integrated Ocean Drilling Program Expedition 304/305 Science Party, 2007, Oceanic core complexes and crustal accretion at slow-spreading ridges: Geology, v. 35, p. 623-626, doi: 10.1130/G23531A.1.

Kelemen, P.B., Kikawa, E., Miller, D.J., and Shipboard Scientific Party, 2004, Proceedings of the Ocean Drilling Program, Initial Reports, Volume 209: College Station, Texas, Ocean Drilling Program, doi: 10.2973/ odp.proc.ir.209.2004

Lavier, L.L., Buck, W.R., and Poliakov, A.N., 2000, Factors controlling normal fault offset in an ideal brittle layer: Journal of Geophysical Research, v. 105, p. 23,431-23,442, doi: 10.1029/2000JB900108.

Lin, J., Purdy, G.M., Schouten, H., Sempéré, J.-C., and Zervas, C., 1990, Evidence from gravity data for focused magmatic accretion along the MidAtlantic Ridge: Nature, v. 344, p. 627-632, doi: 10.1038/344627a0.

Michael, P.J., Langmuir, C.H., Dick, H.J.B., Snow, J.E., Goldstein, S.L., Graham, D.W., Lehnert, K., Kurras, G., Jokat, W., Mühe, R., and Edmonds, H.N., 2003, Magmatic and amagmatic seafloor generation at the ultraslowspreading Gakkel ridge, Arctic Ocean: Nature, v. 423, p. 956-961, doi: 10.1038/nature01704.

Ohara, Y., Yoshida, T., Kato, Y., and Kasuga, S., 2001, Giant megamullion in the Parece Vela backarc basin: Marine Geophysical Researches, v. 22, p. 47-61, doi: 10.1023/A:1004818225642.

Okino, K., Matsuda, K., Christie, D.M., Nogi, Y., and Koizumi, K., 2004, Development of oceanic detachment and asymmetric spreading at the AustralianAntarctic Discordance: Geochemistry, Geophysics, Geosystems, v. 5, doi: 10.1029/2004GC000793.

Reston, T.J., Weinrebe, W., Grevemeyer, I., Flueh, E.R., Mitchell, N.C., Kirstein, L., Kopp, C., Kopp, H., and Participants of Meteor 47/2, 2002, A rifted inside corner massif on the Mid-Atlantic Ridge at $5^{\circ} \mathrm{S}$ : Earth and Planetary Science Letters, v. 200, p. 255-269, doi: 10.1016/S0012-821X(02)00636-2.

Rubin, A.M., 1995, Propagation of magma-filled cracks: Annual Review of Earth and Planetary Sciences, v. 23, p. 287-336, doi: 10.1146/annurev. ea.23.050195.001443.

Spencer, J.E., 1999, Geologic continuous casting below continental and deepsea detachment faults and at the striated extrusion of Sacsayhuamán, Peru: Geology, v. 27, p. 327-330, doi: 10.1130/0091-7613(1999)027 $<0327$ :GCCBCA $>2.3$. CO 2 .

Thatcher, W., and Hill, D.P., 1995, A simple model for the fault-generated morphology of slow-spreading mid-ocean ridges: Journal of Geophysical Research, v. 100, p. 561-570, doi: 10.1029/94JB02593.

Tucholke, B.E., Lin, J., and Kleinrock, M.C., 1998, Megamullions and mullion structure defining oceanic metamorphic complexes on the Mid-Atlantic Ridge: Journal of Geophysical Research, v. 103, p. 9857-9866, doi: 10.1029/98JB00167.

Tucholke, B.E., Fujioka, K., Ishihara, T., Hirth, G., and Kinoshita, M., 2001, Submersible study of an oceanic megamullion in the central North Atlantic: Journal of Geophysical Research, v. 106, p. 16,145-16,161, doi: 10.1029/2001JB000373.

Manuscript received 24 November 2007

Revised manuscript received 7 February 2008

Manuscript accepted 19 February 2008

Printed in USA 